\title{
The Role of the University Library in the War Effort, with Special Reference to the Midwest
}

Mr. Thompson, assistant to the librarian, Iowa State College Library, prepared this paper for the University Libraries Section of A.C.R.L., June 24, 1942.

$\mathrm{T}$ HE TOTAL WAR of the I940's has a peculiar significance for universities and their libraries. Perhaps as much as any other institutions of modern civilization they represent values which our enemies want to destroy and they also harbor the intellectual resources which are of vital importance for ultimate victory. University librarians have a special stake in this war and they have a special role in its prosecution.

It will be to the everlasting credit of some administrators of American universities that they were among the first to attempt to awaken America to the dangers confronting her. In a few cases university librarians also assumed their full responsibility to inform and to educate America for the present crisis. On the other hand, a recent survey showed that some university librarians have been rather hesitant about inaugurating a program for war activities without prodding from the president's office. ${ }^{1}$

To be sure, the university librarian

1 "College and University Libraries and National Defense." College and Research Libraries 3:18-42, December, I94I. does not have the privilege of leadership in the university in most cases but he does have the responsibility of advising and assisting the administration. Most university presidents will be receptive to any proposal which their librarians might bring before them for promoting the cause of America in this war. Here, then, is a unique opportunity for university librarians to show that the key to cordial relations with their superiors is cooperation and initiative, not hesitancy and timidity.

The total war effort calls for total cooperation, and both the administration and the teaching staff expect it from the library. As American universities encounter new emergencies, the library must reinterpret its functions accordingly. We need reinterpretation rather than reorganization, for, with few exceptions, the university library's clientele remains the same as in peacetime, and the real change is emphasis on subject matter. While the university library must follow these trends in subject emphasis, this circumstance does not imply a passive role for the librarian. If he sees his university lagging behind others or if he sees facilities which are not being used for the full benefit of the nation, it is his duty to urge the administration and the faculty to do something about it. In order to effect full coopera- 
tion it is most desirable that librarians serve on the university's committee on war activities. At the Iowa State College, for example, it has been beneficial for both the library and the institution as a whole to have librarians serving on this committee along with representatives from science, agriculture, and engineering.

\section{Priority among the Clientele}

It would be difficult to say which element of a university library's clientele should be given priority in either wartime or peacetime. But today our hopes are concentrated on the undergraduates - the young men and women on whom we depend not only to win the war but also to build a new world in the American Century. These students are perhaps more in need of sound guidance than any student generation of modern times. Three years ago they believed that all war is unconditionally evil; today they are told they must fight one. Three years ago they believed that America was unconcerned with the fate of the rest of the world; today they are told that democracy at home depends on the restoration of democracy on the Continent.

If it is true, as the Librarian of Congress has stated, that the responsibility for this confused state of mind among our young people rests upon irresponsible writers, then it is the duty of university librarians to place before their undergraduates the books which will help them understand public affairs and their own place in the world of today. No means of bringing books to students can be neglected. We cannot wait for students to come to books. Deposit collections should be placed in dormitories, fraternity houses, and the student union, and no great damage will be done if the most popular books are purchased in multiple copies. Neither should we hesitate to collect ephemeral materials of a type ordinarily discarded. The university library need not stop its activity with the collection and distribution of books. It can post maps of war areas and set up displays wherever students will see them. It is not beneath the dignity of a research library to post the daily newspaper, and staff members who are familiar with public affairs should tear themselves away from their more recondite bibliographical activities long enough to direct student discussion groups and conduct radio programs.

\section{Services to the Faculty}

Wartime services to the faculty present tasks of a different order, not at all comparable with services to students. Although some of us are perhaps more in need of "morale" than many students, nevertheless our work as specialists in various subject fields is a clear-cut matter of technical service to the nation's war effort. Accordingly, library services to the faculty in wartime will be essentially the same as in peacetime, but today we must re-examine our policies to eliminate any hindrance to research which is even remotely pertinent to the war effort. In peacetime it might be pardonable to tell a patron that a volume is in bindery or that it cannot be located or that it never circulates, but today, if that volume can be of any possible use in wartime research, no effort should be spared to get it to the right man at the right time. And here is a note for the future. Just as war industries perfect techniques which will later raise civilian standards of living, so also may research libraries develop new services and new skills which will reaffirm their places in the world of the future. 
Research workers throughout the region represent a third category of library patrons which must be given special attention in wartime. New war industries and new war research laboratories are being organized; new agricultural programs are in effect; older institutions, like the universities and experiment stations, are reorientating their activities. These new activities will attract scholars who need the services of a well-organized research library. In order to save time as well as to facilitate economical operation of interlibrary loan, research libraries should publicize widely their resources and willingness to lend books. In serving these groups we should bear in mind the danger of inflated statements of resources and promises of services which cannot be performed, sins which we might overlook indulgently in peacetime but which are highly reprehensible when the success or failure of wartime research is at stake.

\section{Citizens of Small Communities}

A fourth class of borrowers whose needs are intensified in wartime is the citizenry of small communities whose local libraries cannot meet the deluge of requests for books on war technology and public affairs. An unstinting policy of interlibrary loan and reference service will be of great importance in the drive for an unyielding home front, better workers for our war industries, increased food production, and a renewed confidence among the people at large in the value of higher institutions and their libraries. It will be a pardonable case of war profiteering on the part of state institutions if they keep an eye on the future and win the goodwill of the electorate for their patriotic service.

The interpretation of these wartime services, particularly for research workers, will vary in different parts of the country. In the Midwest the traditional emphasis is on agriculture and the production, processing, and consumption of food and clothing, but there is also an equally significant need for industrial research. It is in the latter field that the ingenuity of American scholarship is called upon for the greatest effort, for war technology is the one aspect of physical production in which America has not enjoyed a position of eminence. For both strategic and economic reasons many war industries are moving to the Midwest, and this shift will call for readjustments in the program of university libraries to serve research workers who are not residents of their own campuses.

\section{Task in Middle West}

There is a second and more difficult task for Midwestern university libraries. The citizens of this region have not been as aware of the dangers facing America as citizens of the east and west coasts. To a large measure this condition may be traced to the failure of the book, as the President of the A.L.A. has put it. It is the failure of the people to read and the failure of librarians to make them want to read. University librarians, as well as public librarians, must bear their share of the guilt. Today, when healthy thinking on international politics is essential to our survival, we must bring books to the people, to students and faculty members, and to clubwomen and workers in war industries.

It may be said fairly that many university libraries have performed distinctive services along this line. At the Iowa State College this work began considerably before the outbreak of war and without any urging from outside agencies. Its pro- 
gram was simply to get students enthusiastically interested in international affairs. While the book is the natural medium for a library in any action program, it is essentially a passive element, waiting for the reader to come to it. At Iowa State no pains were spared to bring the reader to the book. Not only the traditional reading list but also the college's radio station and exhibit cases all over the campus were utilized.

\section{Issuing Reading Lists}

In issuing a reading list every effort was made to compose a pamphlet that would be attractive and yet contain outlines for serious discussion. Since the pamphlet was designed not only for students but also for citizens throughout the state, it was thought most advisable for recommended books to be chosen neither by librarians alone nor by faculty members alone. University instructors tend to select reading material that is either above the heads of the people or unavailable in smaller libraries. On the other hand, it is rather presumptuous on the part of a librarian to attempt to draw up an authoritative reading list in any special field without the advice of someone trained in that field. Accordingly, the outline entitled The Background of the $W$ ar was designed in the form of a running discussion with annotated titles of books and pamphlets, and both the text and recommended readings represented the joint efforts of members of the library staff and the department of history and government. It has been used widely by study groups and clubs throughout the state and by student discussion groups in Ames. Justification of this method of selecting books is furnished by the fact that it was used by many public libraries as a buying guide.
The program could not stop with the publication of a study outline. The university library can offer other services by utilizing fully the talent of its staff and the resources of its collection. Accordingly, a folder describing $W$ ar Services of the Iowa State College Library Available to All Citizens of the State of Iowa was issued. The mailing list included state officials, manufacturers, colleges, public schools, libraries, county, state, and national war agencies, and local clubs interested in public affairs. The availability of interlibrary loans, a service which citizens at large and even many smaller libraries use relatively lightly, was specifically emphasized; the library offered its services as a clearing house for all information related to the war effort; it called for suggestions for its radio programs and offered to help secure speakers and discussion leaders; and it offered to distribute The Background of the $W$ ar and give any help on questions which might arise from its use. The latter was somewhat embarrassing: The Background of the $W$ ar was exhausted in two weeks and additional requests from people who were using it have taxed to the utmost the facilities of the reference department. The library has been able to reach more citizens than ever before by calling attention to its wartime services, and thus it is not only performing yeoman service as a war information center but is also laying the groundwork for closer relations with citizens at large and small libraries.

\section{Expanded Service to Students}

On the campus The Background of the War pointed the way for expanded library service to students. As early as the fall of I94I small packets of two or three books such as Berlin Diary and No Other 
Road to Freedom had been deposited in fraternities, dormitories, and sororities. Later these volumes were supplemented by pamphlets chosen largely from titles listed in The Background of the $W a r$, and the collections thus assembled have been used as the basis for the programs of over fifty student discussion groups. It is intended that student discussions shall be based on the solid foundation of reading rather than personal opinion.

It is not out of place at this point to mention a general course of lectures entitled "The Citizen and the World Crisis" which was organized at the suggestion of the president of the college shortly after the publication of The Background of the $W$ ar. It followed the broad outlines of the library's pamphlet and it was open to students for credit as well as to other qualified persons. The individual lectures were given by authorities in the various fields covered, and the library posted for each meeting voluntary reading lists furnished by the lecturers.

\section{All Abilities Utilized}

While the library's natural province is to provide all information available from books, it was felt that in this crisis all capabilities of the staff should be fully utilized. The librarian has actively engaged in leading one discussion group in a women's residence hall and has organized and encouraged others. The assistant librarian in charge of public service has directed weekly forums on public affairs which are attended by several hundred students. Library radio programs consisting of reviews of books and articles shifted their emphasis to subjects of immediate significance for the war effort, and further changes are contemplated to keep step with the shifting fortunes of war.
Within the library itself the problem of war information was handled along the lines which seemed to be best adapted to its individual situation. A separate war information center was not established, the problem of space alone being sufficient reason for a library which has over 100,000 volumes in storage. However, it was found that the reference department, cooperating with the display committee, could perform most of the obvious functions of a war information center. Two large upright display cases, formerly used for propaganda analysis, were turned over to pamphlets on the war and international affairs. In addition, two other large double-faced display cases contain pamphlets on the armed forces and civilian defense. These two collections, which are specifically for browsing purposes, are supplemented by a constantly changing war display of books placed on tables in the main vestibule of the library and at other points on the campus where they will attract the attention of students. Posters and maps, which are frequently changed, are put up on one bulletin board at the entrance of the library, while another extra large bulletin board, ordinarily kept out of sight for esthetic reasons, has been resurrected to do the humble but significant job of displaying the daily newspaper. There are also special collections of ephemeral documents of a type ordinarily ignored in a technological library. Traditional policy is no barrier to meeting the exigencies of war, and indeed it is fortunate that we have this opportunity to review the advisability of changing it or of continuing it after the war.

\section{Research Projects and Special Courses}

Important as these activities are for preparing our students for the war and 
the peace, they pale into relative insignificance beside the research projects and special courses in war technology which are being conducted at all of our great scientific schools. Requests for special services have come not only from faculty members but also from scientists at such new centers of research as the Des Moines and Burlington ordnance plants. In several cases the attention of the latter group has been directed to Ames by the folder on War Services of the Iowa State College Library Available to All Citizens of the State of Iowa. Although it might seem hardly necessary to restate the library's services to its own patrons, it was decided to pursue further the policy of action, and accordingly a two-page mimeographed statement on $W$ ar Services of the Iowa State College Library Designed to Meet the Needs of Students and Faculty Members was issued. This statement was widely circulated and proved helpful.

The problem of providing adequate service to research workers and students of war technology is primarily one of intensified service rather than of increasing resources, for it is impossible to augment our basic research collections to any considerable degree in wartime. The reference department at the Iowa State College Library has been forced to utilize existing resources more intensively than ever before. We cannot get the last twenty years of Zeitschrift für das gesamte Schiess- und Sprengstoffwesen but we can dig much of the information out of the Army's splendid series of technical manuals ; we cannot purchase foreign and outof-print titles in the bibliography of war damage compensation but we can make judicious use of the current flood of documents, pamphlets, and books on the subject.

\section{New Courses Require New Books}

New courses offered by the college in a few fields not ordinarily emphasized required that present holdings be supplemented for class work. For example, the library had purposely not chosen to be a depository for the publications of the Hydrographic Office, but new courses in celestial navigation required that these materials be secured at once. The same was true for several other new courses. Still, it was felt that it was less expensive to purchase these books when the occasion arose than to store them for years as dead wood.

The library has been able to meet practically all requests from prospective defense workers outside of Ames who want to train themselves for skilled trades. It has not held small public libraries with poor bibliographical resources to the customary interlibrary loan regulation that a specific title, fully verified, be requested. There have been dozens of requests for such items as "something on utilization of waste products" or "manuals on splicing cables." To point out specifically what was available in some of these fields, the library issued and circulated widely in early I94 I a List of Books and Publications for the Mechanical Trades, in Connection with Defense Activities, compiled by two members of the department of industrial education. Later in the spring, when the national vocational training program for defense industries was in full swing, the library published a Partial Bibliography of Teaching Methods in Industrial Arts Education, $1930-40$, for distribution to teachers of industrial arts throughout the state.

\section{Program Directed at Iowa}

This wartime program has been pri- 
marily directed at the state of Iowa. Within the state it is limited to fields not covered by the State University of Iowa Libraries or by the State Traveling Library. Outside of the state the library's resources have been made available wherever such service could not be rendered by corresponding institutions. The library's war program has been designed to promote efforts toward greater cooperation among research libraries that were developing so rapidly in the prewar years.

The work of the Iowa State College Library as described in this paper is probably not unique. Certainly all libraries could be much more active in providing war services than they are at present. For example, it is planned this summer at the Iowa State College Library to review and evaluate the war program completely. The professional staff, with the cooperation of the faculty and the college's Committee on Civilian War Activities will study during the summer all possibilities for further war services which are needed but not now provided. A continuing policy of re-examination and reinterpretation of established policy is necessary if we are to make our maximum contribution to the war effort and to justify the place of the university library in a rapidly changing civilization.

\section{Friends of the Library of Brown University}

\section{(Continued from page Io)}

\section{The Cataloger}

Stone walls do not a prison make, it's said, Nor books a library-if they're not read. Full many a book may blush unseen, unless It feels the cataloger's deft caress.

Her loving touch makes hidden wonders known;

She stores the corn the author has but sown.

Each single book may shed a little light;

But grouped with others, it can vanquish night.

So, Cataloger, you must make the bed;

Tuck each book in; see that a prayer is said Against misplacement on the teeming shelves. There let it sleep, till prowling scholar delves

Deep in the stacks. Led by your pointing pen,

He wakes it gleefully-to live again.

When Friends of the Library wax lyric over cataloging, they must be going places!
It is the growth of this kind of educated interest that the Friends of the Library are building up. "The raising of money is not the chief desire of the Friends. It is not even an important one. ... This is a society of persons who are lovers of books, interested in the Library of Brown University and its growing usefulness." But they have raised money and they will raise more-inevitably, as interest and knowledge of library activities and needs increase. And whether they raise money or not, they are still a good alumni education organization, alumni education is a proper function of the university (whether the alumni are its own or somebody else's), and educated alumni are, in the long run, the university's best asset and, thus, assets of the university library. 